Research article

Open Access

\title{
BCoR-L1 variation and breast cancer
}

\author{
Felicity Lose 1,2, Jeremy Arnold1', David B Young ${ }^{1}$, Carolyn J Brown³, Graham J Mann4, \\ Gulietta M Pupo ${ }^{4}$, The Kathleen Cuningham Foundation Consortium for Research into Familial \\ Breast Cancer, Kum Kum Khanna1, Georgia Chenevix-Trench ${ }^{1}$ and Amanda B Spurdle1
}

\author{
${ }^{1}$ Cancer and Cell Biology Division, Queensland Institute of Medical Research, 300 Herston Road, Brisbane, Queensland, Australia, 4006 \\ ${ }^{2}$ School of Medicine, Central Clinical Division, University of Queensland, Royal Brisbane Hospital, Corner Butterfield Street and Bowen Bridge Road, \\ Brisbane, Queensland, Australia, 4029 \\ ${ }^{3}$ Department of Medical Genetics, Molecular Epigenetics Group, University of British Columbia, 2329 West Mall, Vancouver, BC, Canada, V6T 1Z4 \\ 4Westmead Institute for Cancer Research, University of Sydney at Westmead Millennium Institute, Westmead Hospital, Darcy Road, Westmead, New \\ South Wales, Australia, 2145
}

Corresponding author: Amanda B Spurdle, Amanda.Spurdle@qimr.edu.au

Received: 30 Apr 2007 Revisions requested: 29 Jun 2007 Revisions received: 23 Jul 2007 Accepted: 16 Aug 2007 Published: 16 Aug 2007

Breast Cancer Research 2007, 9:R54 (doi:10.1186/bcr1759)

This article is online at: http://breast-cancer-research.com/content/9/4/R54

(c) 2007 Lose et al.; licensee BioMed Central Ltd.

This is an open access article distributed under the terms of the Creative Commons Attribution License (http://creativecommons.org/licenses/by/2.0), which permits unrestricted use, distribution, and reproduction in any medium, provided the original work is properly cited.

\begin{abstract}
Introduction BRCA1 is involved in numerous essential processes in the cell, and the effects of BRCA1 dysfunction in breast cancer carcinogenesis are well described. Many of the breast cancer susceptibility genes such as BRCA2, p53, ATM, $C H E K 2$, and BRIP1 encode proteins that interact with BRCA1. BCL6 corepressor-like 1 (BCoR-L1) is a newly described BRCA1-interacting protein that displays high homology to several proteins known to be involved in the fundamental processes of DNA damage repair and transcription regulation. BCoR-L1 has been shown to play a role in transcription corepression, and expression of the X-linked BCoR-L1 gene has been reported to be dysregulated in breast cancer subjects. $B C o R-L 1$ is located on the $X$ chromosome and is subject to $X$ inactivation.
\end{abstract}

Methods We performed mutation analysis of 38 BRCA1/2 mutation-negative breast cancer families with male breast cancer, prostate cancer, and/or haplotype sharing around $B C o R-L 1$ to determine whether there is a role for $B C o R-L 1$ as a high-risk breast cancer predisposition gene. In addition, we conducted quantitative real-time PCR (qRT-PCR) on lymphoblastoid cell lines (LCLs) from the index cases from these families and a number of cancer cell lines to assess the role of $B C o R-L 1$ dysregulation in cancer and cancer families.

Results Very little variation was detected in the coding region, and $\mathrm{qRT}-\mathrm{PCR}$ analysis revealed that $B C o R-L 1$ expression is highly variable in cancer-free subjects, high-risk breast cancer patients, and cancer cell lines. We also report the investigation of a new expression control, DIDO1 (death inducer-obliterator 1 ), that is superior to $G A P D H$ (glyceraldehyde-3-phosphate dehydrogenase) and UBC (ubiquitin C) for analysis of expression in LCLs.

Conclusion Our results suggest that BCoR- $L 1$ expression does not play a large role in predisposition to familial breast cancer.

\section{Introduction}

Less than $40 \%$ of familial breast cancer can be attributed to mutations in the high-risk genes BRCA1 and BRCA2 despite their high penetrance $[1,2]$. Syndromes displaying a predisposition for breast cancer such as Li-Fraumeni syndrome (resulting from p53 gene mutations) [3], ataxia telangiectasia (ataxia telangiectasia-mutated, or ATM, gene) [4], and Cowden syn- drome (phosphatase and tensin homologue, or PTEN, gene) [5] are estimated to account for no more than $10 \%$ of familial breast cancer collectively, and additional moderate-risk genes such as CHEK2 [6] and the recently reported BRIP1 (also called $B A C H 1)$ [7] and PALB2 [8,9] account for an even smaller percentage. This leaves a large proportion of the genetic basis of familial breast cancer unexplained.

$\overline{\mathrm{ATM}}=$ ataxia telangiectasia-mutated; $\mathrm{BCoR}-\mathrm{L} 1=\mathrm{BCL} 6$ corepressor-like $1 ; B R C A X=B R C A 1 / 2$ mutation-negative; $\mathrm{DHPLC}=$ denaturing high-performance liquid chromatography; $D I D O 1=$ death inducer-obliterator $1 ; \mathrm{ER}=$ estrogen receptor; $\mathrm{ESE}=$ exonic splice enhancer; $G A P D H=$ glyceraldehyde-3-phosphate dehydrogenase; HDAC = histone deacetylase; $\mathrm{kConFab}=$ Kathleen Cuningham Foundation Consortium for Research into Familial Breast Cancer; $\mathrm{LCL}=$ lymphoblastoid cell line; $\mathrm{LOH}=$ loss of heterozygosity; $\mathrm{PCR}=$ polymerase chain reaction; $\mathrm{PR}=$ progesterone receptor; qRT-PCR $=$ quantitative real-time polymerase chain reaction; $U B C=$ ubiquitin $\mathrm{C}$. 
Interestingly, BRCA2, p53, ATM, CHEK2, and BRIP1 all interact with the multifunctional tumour suppressor, BRCA1. BRCA1-interacting proteins are logical breast cancer candidates for two reasons. First, they are likely to be involved in some of the important roles of BRCA1 such as genome maintenance, transcription regulation, and cell cycle control and, if mutated, may result in the same highly penetrant and damaging effect as a BRCA1 mutation. Second, mutations in these interacting genes may prevent BRCA1 from performing vital functions, resulting in the same acute effect as a BRCA1 mutation itself. Recently, Pagan and colleagues [10] described the characterisation and functional analysis of a novel BRCA1-interacting protein, BCL6 corepressor-like 1 (BCoR-L1), that displays homology to several proteins involved in pathways such as DNA damage repair (BARD1 and Drosophila recombination repair protein 1) and transcription regulation (BCoR). Functional analysis thus far has revealed a role for BCoR-L1 in transcriptional corepression [10], placing it in a large group of proteins involved in the regulation of proliferation and apoptosis [11]. It is well established that uncontrolled overexpression of oncogenes and repression or mutation of tumour suppressors contribute to tumourigenesis by disturbing these vitally important and tightly controlled cellular processes [12].

Evidence that BCoR-L1 operates primarily as a transcription corepressor includes its ability to dramatically reduce reporter gene expression through an interaction with the CtBP (carboxyl-terminal binding protein) corepressor via a PLDLS motif and the fact that it associates with a number of class II histone deacetylases (HDACs), factors also involved in transcription repression [10]. Similarly, BRCA1 interacts with a number of proteins involved in chromatin remodelling and transcription control [13]. Like BRCA1, BCoR-L1 is also involved in maintaining genomic stability after DNA damage.

In addition to its interaction with BRCA1, there is indirect evidence to suggest that BCoR-L1 may behave as a tumour suppressor. The BCoR-L1 protein appears to be expressed ubiquitously at low levels (including breast tissue), with high levels in reproductive tissues such as prostate and testes [10]. However, $B C o R-L 1$ expression was found to be decreased in a variety of breast cancer subjects, including $B R C A 1 / 2$ mutation carriers and 'sporadic' breast cancer subjects [14]. In addition, the $B C o R-L 1$ gene is located at $\mathrm{Xq} 26.1$, a region reported to exhibit loss of heterozygosity $(\mathrm{LOH})$ in many tumour types, including those of the breast [15-17]. BCoR-L1 is subject to complete $X$ inactivation [18], and interestingly, an increased frequency of skewed $X$ inactivation has been reported in both ovarian [19] and early-onset $B R C A 1 / 2$ mutation-negative $(B R C A X)$ breast $[20,21]$ cancer populations. It has been proposed that skewed $X$ inactivation could provide a novel mechanism for nonrandom expression of a mutant tumour suppressor gene and thereby contribute to tumourigenesis.
We sought to determine whether there is a role for $B C o R-L 1$ as a high-risk breast cancer predisposition gene by screening the coding region of the gene in $38 B R C A X$ breast cancer families by means of the highly sensitive mutation detection technique, denaturing high-performance liquid chromatography (DHPLC). The majority of families were chosen specifically for the presence of male breast cancer and/or early-onset prostate cancer, in combination with being a high-risk female breast cancer family, for two reasons. We hypothesised that an X-linked gene may be involved in these male cancer because males carry only one copy of the $\mathrm{X}$ chromosome and because $B C o R-L 1$ has been found to be expressed highly in the prostate [10]. A small number of breast cancer families in which the affected individuals showed haplotype sharing around the $B C o R-L 1$ locus were also included in this study. In addition, we conducted quantitative real-time PCR (qRT-PCR) on lymphoblastoid cell lines (LCLs) from members of these families and a number of cancer cell lines to assess the role of $B C o R-L 1$ expression in cancer and cancer families. We assessed $B C o R-L 1$ expression in LCLs from breast cancer cases to determine whether $B C o R-L 1$ expression was altered in familial breast cancer cases and, if so, whether this was associated with the presence of genetic variation. Analysis of $\mathrm{X}$ inactivation status of $B C o R-L 1$ was also undertaken in order to assess the likely mode of inheritance of $B C o R-L 1$ as a candidate tumour suppressor gene.

\section{Materials and methods $X$ inactivation status analysis}

$\mathrm{X}$ inactivation status was assessed by comparison of $B C o R$ $L 1$ mRNA expression with human-specific primers (forward: CATATGATGTGACGGAATCTC; reverse: CCCTGGACTTTGTTGGGCA) in mouse-human or hamster-human hybrid cell lines containing a human active $X$ chromosome (AHA-11aB1, A23-1aC115, t60-12, GM06318D, CHO-01416-M) or a human inactive $X$ chromosome (LT23-1E2, t48-1a-1Daz4a, t11-4Aaz5, t75-2maz34-1a, t86-B1maz1b-3a, X8-6T2S1, $\mathrm{CHO}-01416-07)$. Comparison of expression levels between the two groups of cell lines (containing an inactive versus inactive human $\mathrm{X}$ chromosome) was used to establish whether $B C o R-L 1$ is subject to $X$ inactivation.

\section{Subjects}

Multiple-case breast cancer families were ascertained through the Kathleen Cuningham Foundation Consortium for Research into Familial Breast Cancer (kConFab) [22]. Inclusion criteria for all families in this study required that the family be classified as category 3 (high-risk) according to the National Breast Cancer Centre guidelines [23] and that the family not possess any known mutations in the BRCA1 or BRCA2 genes (BRCAX) at the time of initiation of the study. Ethics approvals were obtained from the ethics committees of the Peter MacCallum Cancer Institute (East Melbourne, Victoria, Australia) and the Queensland Institute of Medical Research (Brisbane, Queensland, Australia), and all subjects gave written informed 
consent. Male breast cancer families selected for study $(n=$ 21 ) all contained one or more male breast cancer cases occurring on the same side of the family as at least three female breast cancer cases. A total of 11 male breast cancer cases and 16 female index cases (the youngest breast cancer case in the family from which biospecimens were available) were screened from these families. Prostate/female breast cancer families ( $n=12$ ) were chosen to contain at least one 'earlyonset' prostate cancer case (cancer diagnosed at not more than 60 years of age) on the same side of the family as three or more female breast cancer cases. A total of 2 prostate cancer cases and 12 index female breast cancer cases were analysed from these families. Pedigrees were examined to ensure the absence of male-to-male transmission of the disease in these families because this would imply involvement of an autosomal gene. Additionally, families with female breast cancer only $(n=7)$ were selected for analysis because they demonstrated haplotype sharing in the same chromosomal region as BCoR-L1 (DXS1001, DXS1047, and DXS1227; LOD [logarithm of the odds] score greater than 0.5; data not shown) and are referred to as $B C o R-L 1$ haplotype sharing families. Two $B C o R-L 1$ variants were found in one family and were then genotyped in all family members from which biospecimens were available $(n=12)$. Mutation screening in the kConFab cohort during the course of the study subsequently identified $B R C A 2$ mutation carriers in two male breast cancer families. Control subjects (46 females and 55 males) without cancer or a family history of cancer included subjects ascertained via the Queensland Blood Bank and a group of geriatric controls (average age of 80 years).

\section{Screening for $B C o R-L 1$ variation}

BCoR-L1 is expressed in two isoforms. The most common isoform is 1,711 amino acids in size and lacks exon 9, but the fulllength protein $(1,785$ amino acids long) is derived from the alternative transcript. This study screened the entire coding region of the $B C O R-L 1$ gene, including exon 9 . Primers encompassing the 13 coding exons of $B C o R-L 1$ (and surrounding intronic regions; GenBank: exons 2 to 8: $\underline{Z 82208}$; exons 9 to 14: AL136450) were designed using Primer3 [24] (Table 1). Exon 4 was too large to be amplified at an optimal size for DHPLC analysis and was therefore analysed with 10 overlapping polymerase chain reaction (PCR) fragments. 'Standard' PCR reactions were carried out in a $20-\mu$ l mixture containing $15 \mathrm{ng}$ of genomic DNA, and a final concentration of 20 pmol of each primer, $200 \mu \mathrm{M}$ each of dATP, dCTP, dGTP, and dTTP (Promega Corporation, Madison, WI, USA), $1.5 \mathrm{mM}$ $\mathrm{MgCl}_{2}, 1 \times \mathrm{PCR}$ buffer, and $1 \mathrm{U}$ AmpliTaq Gold polymerase (PE Applied Biosystems, Foster City, CA, USA). Any variation to the reaction is detailed in Table 1, along with a description of 'touchdown' PCR amplification conditions. All products (and $\mathrm{H}_{2} \mathrm{O}$ controls) were visualised on a $1.5 \%$ agarose gel. Male samples were mixed with sequence-confirmed wild-type female PCR product $(2: 1)$ to encourage heteroduplexes to form for successful DHPLC analysis. Samples were denatured by heating to $95^{\circ} \mathrm{C}$ for 5 minutes and cooling to $60^{\circ} \mathrm{C}$ over a period of 30 minutes and then analysed on a Varian Helix DHPLC system (Varian, Inc., Palo Alto, CA, USA) at the recommended melt temperature(s) as determined by the Stanford DHPLC Melt program [25] (Table 1). Analysis of results was carried out using Star Workstation Reviewer software (version 5 , Varian) and any aberrant or shifted profiles were reamplified for confirmation of the aberrant profile by repeat DHPLC before being sequenced using the Big-Dye (version 3.1) sequencing chemistry and PE Applied Biosystems 377 sequencer.

\section{Loss of heterozygosity analysis}

$\mathrm{LOH}$ analysis was carried out on tumour blocks from the $B C o R-L 1$ haplotype sharing family carrying the exon 4 c.516T $>C$ variant, because genotyping analysis revealed that the variant segregated with breast cancer. Macrodissected tumour and adjacent cancer-uninvolved tissue DNA was extracted from tumour blocks by means of a modified version of the method of Levi and colleagues [26], and $2 \mu \mathrm{l}$ of each DNA (plus $20 \mathrm{ng}$ of lymphocyte-derived germline DNA from the same subject) was then added to separate 20- $\mu$ I PCR reactions, as detailed above. Primers used were (forward) TCAACACCCAAATGAGCAAA and (reverse) GAACAGAGTGGGGCACAGAG to give a product of 242 base pairs. 'Touchdown' PCR was used with an annealing temperature of $50^{\circ} \mathrm{C}$. PCR products were then purified (Qiagen Inc., Valencia, CA, USA) and sequenced. $\mathrm{LOH}$ was evaluated by scoring the absence of the allele in the sequencing trace of the tumour, compared to matching germline DNA.

\section{BCoR-L1 expression analysis}

All LCLs and normal and cancer cell lines were grown in RPMI 1640 media with $10 \%$ fetal calf serum and $1 \%$ penicillin/streptomycin. Cell lines used are detailed in Figure 1a. RNA was extracted from LCLs and cell lines using TriReagent (SigmaAldrich, St. Louis, MO, USA) according to the manufacturer's instructions, and $1 \mu \mathrm{g}$ of each sample was placed in a reverse transcription-PCR reaction using Superscript III RNAse $\mathrm{H}^{-}$ Reverse Transcriptase as directed by the manufacturer (Invitrogen Corporation, Carlsbad, CA, USA). qRT-PCR was then carried out in a $15 \mu \mathrm{l}$ reaction containing a final volume of 20 ng of cDNA, 20 pmol of each primer, and $7.5 \mu \mathrm{l}$ of Platinum SYBR Green qPCR Supermix UDG (Invitrogen Corporation). Primer sequences used are detailed in Table 2. qRT-PCR conditions were $50^{\circ} \mathrm{C}$ for 2 minutes and $95^{\circ} \mathrm{C}$ for 2 minutes, 40 cycles of $95^{\circ} \mathrm{C}$ for 20 seconds, $60^{\circ} \mathrm{C}$ for 15 seconds, and $72^{\circ} \mathrm{C}$ for 20 seconds (acquiring) on a Rotor-Gene RG-3000 Real-Time PCR machine (Corbett Research Australia, Mortlake, New South Wales, Australia). All samples were run in duplicate and were repeated if profiles did not replicate according to Rotor-Gene analysis software (version 5). Accordingly, the maximum standard deviation allowed for a pair of duplicates ('Rep. Ct Std. Dev' in analysis software) was low $(\leq 0.2)$. Expression levels were presented as the mean of 
Breast Cancer Research Vol 9 No 4 Lose et al.

Table 1

\begin{tabular}{|c|c|c|c|c|c|c|c|}
\hline Exon & $\begin{array}{l}\text { PCR } \\
\text { fragment }\end{array}$ & Forward primer & Reverse primer & PCR conditions & $\begin{array}{c}\text { Annealing } \\
\text { temperature } \\
\left({ }^{\circ} \mathrm{C}\right)\end{array}$ & $\begin{array}{l}\text { Size } \\
\text { (bp) }\end{array}$ & $\begin{array}{c}\text { DHPLC } \\
\text { temperature } \\
\left({ }^{\circ} \mathrm{C}\right)\end{array}$ \\
\hline 2 & 2 & GGCTGGCTGCTTTAACATTC & CTCCCCAGGCCCTATTGTAT & $2 \mathrm{U}$ Taq, 40 pmol primers, $0.5 \mathrm{M}$ & 54 & 425 & 62 \\
\hline 3 & 3 & AGGTGGTGTTGGCTCAAATC & CAACTCGACCAACCAGGTCT & 40 pmol primers & 54 & 404 & 62 \\
\hline 4 & $4 a$ & TGTGCATGCTATCCTGTCGT & GCTGGCAGAGGACTGAAGTT & 40 pmol primers & 54 & 450 & 62 \\
\hline 4 & $4 \mathrm{~b}$ & GAACTGGAGTCCCTGTGGAG & GAGGGTGGGGGTAGAAGGT & $2 \mathrm{U}$ Taq, $1 \mathrm{mM} \mathrm{MgCl}, 1 \mathrm{M}$ betaine & 54 & 578 & 63 \\
\hline 4 & $4 \mathrm{c}$ & GTCCCCACTCCGGTTCTG & CAGGGAGCGTAAGAGTGGAG & Standard & 54 & 442 & 63 \\
\hline 4 & $4 d$ & TGGTATATATCCCGCCTCCA & GTCCCTTCTGTTTGCTGCTC & 40 pmol primers & 54 & 436 & 57,62 \\
\hline 4 & $4 e$ & СТTCСААСТССАСАGССТСТ & AATGGTGCTGATCAGTGCAG & $2 \mathrm{mM} \mathrm{MgCl}_{2}, 0.5 \mathrm{M}$ betaine & 58 & 459 & 62 \\
\hline 4 & $4 f$ & CTCGCCCTTTGTCATCTTTC & GCTGGTAGGTTTCCCATTGA & $2 \mathrm{mM} \mathrm{MgCl}_{2}$ & 54 & 424 & 62 \\
\hline 4 & $4 g$ & GACAGCCAAGCACAGTGAAA & GCTGAGGGTCAAGAGGACAG & Standard & 54 & 452 & 62 \\
\hline 4 & $4 \mathrm{~h}$ & CTCCTTCGTTCCAGAGCAGG & CCAGGACCAGCTCATGGGAC & Standard & 59 & 314 & 61 \\
\hline 4 & $4 \mathrm{i}$ & AGAGAGCCACСTCTGCTCTG & АCCСCTACGCTTTCCTGTTT & Standard & 54 & 435 & 62 \\
\hline 4 & $4 j$ & AAGGTGGATGGTGATGTGGT & GAGGGGACAGCAGGTCATTA & Standard & 54 & 457 & 62 \\
\hline 5 & 5 & GCAGCTCATGCCTCTAGGTC & АTCCTTGCTCGCTCACCTTA & Standard & 54 & 446 & 62 \\
\hline 6 & 6 & GCAAAAGCGACCAAACTCTC & АATTCCCAACTCGACACCTG & $2 \cup \mathrm{Taq}$ & 56 & 423 & 60 \\
\hline 7 & 7 & TCCTCTGTACATCCCATCCAC & GTAGAGATGCCCGAGGGTTC & $2 \mathrm{mM} \mathrm{MgCl}_{2}$ & 63 & 483 & 62 \\
\hline 8 & 8 & AGGCGTTGCTTTTCTGTGTT & CGCCACACACACCTTCTACA & $2 \mathrm{mM} \mathrm{MgCl}_{2}$ & 57 & 332 & 60 \\
\hline 9 & 9 & ATGACCCTGGTGGATGGATA & GGTTCAAGCACCAGAAGAGC & Standard & 62 & 378 & 61 \\
\hline 10 & 10 & TGGGCAACAGAGTGAGACTG & GCAGGCAAGGTCTTTTGAGT & Standard & 54 & 488 & 62 \\
\hline 11 & 11 & CAGGTGGTTCCCTTGTCCTA & GAGCTGTTCAAGGTGGAAGG & Standard & 54 & 399 & 61 \\
\hline 12 & 12 & СТTСТСССААТTСССТTAGСC & AAAGCCAGGGAGAAGAAAGG & $0.5 \mathrm{M}$ betaine & 54 & 454 & 60 \\
\hline 13 & 13 & ССССТАТАТGСТССССТTАСА & TTGCCAGGTCTTCACTTCCT & Standard & 54 & 273 & 60 \\
\hline 14 & 14 & ТTССТССАGССТССТTСААТ & CCCGGGACCTCTTGTCCT & 40 pmol primers & 54 & 595 & 62 \\
\hline
\end{tabular}

a'Touchdown' polymerase chain reaction (PCR) amplification conditions were as follows: denaturation at $94^{\circ} \mathrm{C}$ for 10 minutes, followed by two cycles of $94^{\circ} \mathrm{C}$ for 30 seconds, 30 seconds at the fragment annealing temperature $\left(\mathrm{T}_{A}\right)+6^{\circ} \mathrm{C}$, and $72^{\circ} \mathrm{C}$ for 30 seconds. The conditions remained the same for the rest of the PCR except for the $T_{A}$, which consisted of two cycles at $\left(T_{A}+4^{\circ} \mathrm{C}\right)$, then two cycles at $\left(T_{A}+2^{\circ} \mathrm{C}\right)$, and (finally) 35 cycles at the $T_{A}$. A final extension step was conducted at $72^{\circ} \mathrm{C}$ for 7 minutes. bp, base pairs; DHPLC, denaturing high-performance liquid chromatography.

two duplicates, normalised to expression of either GAPDH (all samples) or DIDO1 (death inducer-obliterator 1) (LCLs only). Expression levels of different groups were compared using the Student $t$ test (two-tailed).

\section{Assessment of expression controls for lymphoblastoid cell lines}

RT-PCR expression controls are typically chosen for their stability of expression not only during various phases of the cell cycle, but also between different tissue types. However, it is well known that these characteristics are very difficult to obtain. It has been reported that widely accepted expression controls such as $\beta$-actin and GAPDH show unacceptable variation in expression in a large number of tissues and are therefore not ideal controls [27]. We sought to find a suitable expression control for analysis of expression in LCLs and compared this with two widely used expression controls, GAPDH and ubiquitin $C$ (UBC). Cheung and colleagues [28] used microarray analysis to establish the variability of expression of 5,184 genes in LCLs taken from random individuals. We evaluated the 100 least variably expressed genes for suitability as an LCL expression control for our project via a PubMed [29] search of the literature to identify the genes that (a) had not been reported to be associated with cancer of any kind and (b) were not in a region of $\mathrm{LOH}$ or linkage to any cancer. DIDO1 was chosen according to these criteria.

\section{Results and Discussion}

$B C o R-L 1$ was selected as an interesting breast cancer candidate gene for a number of reasons. BCoR-L1 interacts with the important breast cancer susceptibility gene product, BRCA1, and there is the possibility that BCoR-L1 is involved, with BRCA1, in critical DNA repair and cell growth pathways. Indeed, mutations in repressor proteins have been implicated 
Table 2

\begin{tabular}{lccc}
\hline \multicolumn{2}{l}{ Quantitative real-time polymerase chain reaction primer sequences } \\
\hline Gene & GenBank ID & Forward primer \\
\hline$B C O R-L 1$ & $\underline{\text { AL136450 }}$ & GACCGACATCCTGAACATCC & Reverse primer \\
GAPDH & NT 009759 & CTGCACCACCAACTGCTTAG & GTCTTCTGGGTGGCAGTGAT \\
$U B C$ & NM 021009 & CTTGTTTGTGGATCGCTGTG & GTGTCACTGGGCTCAACCTC \\
$D I D O 1$ & NT 011333 & GCCTGAATGTGAGGGTTACG & ACAATCGCCATGAAACCATT
\end{tabular}

$B C o R-L 1, B C L 6$ corepressor-like 1; DIDO1, death inducer-obliterator 1; GAPDH, glyceraldehyde-3-phosphate dehydrogenase; UBC, ubiquitin C.

in several diseases, including cancer [30]. For example, functional mutations in the transcriptional repressor $R b$ gene result in dysregulation of cell cycle control [31]. In addition, the $B C O R-L 1$ gene is located at Xq26.1, a region that exhibits $\mathrm{LOH}$ in cancers, including breast cancer, and there is some evidence that $B C o R-L 1 \mathrm{mRNA}$ expression is deregulated in breast cancer. Skewed $X$ inactivation has been reported in breast and ovarian cancer subjects, indicating the possible presence of an $\mathrm{X}$-linked cancer predisposition gene.

\section{$X$ inactivation status analysis}

Analysis of the hybrid cell lines showed that $B C O R-L 1$ was not expressed in 4/5 hybrid cell lines containing an inactive $X$ chromosome and was expressed at very low levels in the fifth cell line t48-1a-1Daz4a, using hybrids containing an active $X$ chromosome as reference. These results indicate that $B C o R$ $L 1$ is subject to $X$ chromosome inactivation in humans, which is in agreement with the study of Carrel and Willard [18], who showed that the proximal UTP14A gene was expressed in 3/ 9 hybrids whereas BCOR-L1 (FLJ11362) was silent in all 9. As some of the hybrids in this study overlap, BCOR-L1 is silenced in $11 / 11$ hybrids studied to date. The fact that $B C o R-$ $L 1$ is subject to $X$ inactivation suggests that only a single mutational event in the $B C o R-L 1$ gene would be required to initiate tumourigenesis.

\section{Variation in the BCoR-L1 gene}

DHPLC analysis of the coding region of $B C o R-L 1$ in 48 members of 38 high-risk $B R C A X$ breast cancer families revealed only four different sequence variations (Table 3 ). A nucleotide variation in exon 4 (c.516T $>C$; p.N172N) was found in one breast cancer family known to share a haplotype at the $B C o R$ $L 1$ locus. This variant was carried primarily by breast cancer cases from this family (Figure 2). However, this c.516T>C nucleotide substitution is not likely to be functional because it does not result in an amino acid change and is not predicted by in silico modelling to have any effect on mRNA structure (MFOLD [32]) and the wild-type T allele is not conserved in either mouse or rat (PipMaker [33]). Investigation of exonic splice enhancer (ESE) sites by means of ESEfinder (version 2.0) [34] revealed that the variant allele produces an SC35 site (of value 2.455), but this score is very close to the SC35 threshold of 2.383. Similar analysis using Rescue ESE [35] revealed no change. Additionally, analysis of codon usage of the AAT codon (wild-type) in the human genome versus the AAC codon (variant) showed that the two codons are used at similar frequencies (16.8 versus 19.1/1,000 codons) [36]. Finally, LOH analysis of the c.516T>C variant gave no evidence of the change being involved in tumourigenesis. $\mathrm{LOH}$ analysis of tumour blocks and germline DNA from all four breast cancer cases in this family revealed either loss of the variant allele or no $\mathrm{LOH}$ (data not shown), indicating that this variant is unlikely to be pathogenic.

The intron 5 c.3608-156C>T variant was found only in members of the family who carried the exon 4 synonymous variant p.N172N (Figure 2). Due to its deeply intronic location, c.3608-156C $>\mathrm{T}$ is not predicted to have any functional effect. SpliceSiteFinder did not predict any changes to splicing as a result of this nucleotide substitution [37]. Furthermore, mRNA expression analysis (see below) of $B C o R-L 1$ in two of the variant-carrying breast cancer cases and one wild-type nonbreast cancer subject from this family revealed no evidence for consistent differences in expression in LCLs. Relative to the unaffected wild-type family control, one variant carrier displayed increased expression and the other displayed decreased expression (Figure 3a,b; subjects marked with \#).

The two other variants detected in and around the $B C o R-L 1$ coding region in this study, c.625G $>A$ (p.G209S) and c.5075+21C $>$ T, were found in similar frequencies in the control sample. Similarly, there were no major differences between groups when the study sample was divided into male breast, prostate, or $B C o R-L 1$ haplotype sharing families. Although the exon 4 p.G209S variant is a missense amino acid substitution, this change is predicted by SIFT (Sorting Intolerant From Tolerant) to be 'tolerated' [38]. p.G209S is also located in a region of BCoR-L1 that is not thought to be involved in BRCA1 interaction or transcription repression [10]. Additionally, qRT-PCR analysis of $B C o R-L 1$ expression in breast cancer cases carrying the p.G209S and c.5075+21C $>$ T variants showed no differences when compared with controls (Figure 3c,d), with overlapping standard deviations for expression. Furthermore, both variants were present in individuals found to carry pathogenic BRCA2 mutations during the course of the study. 
Figure 1

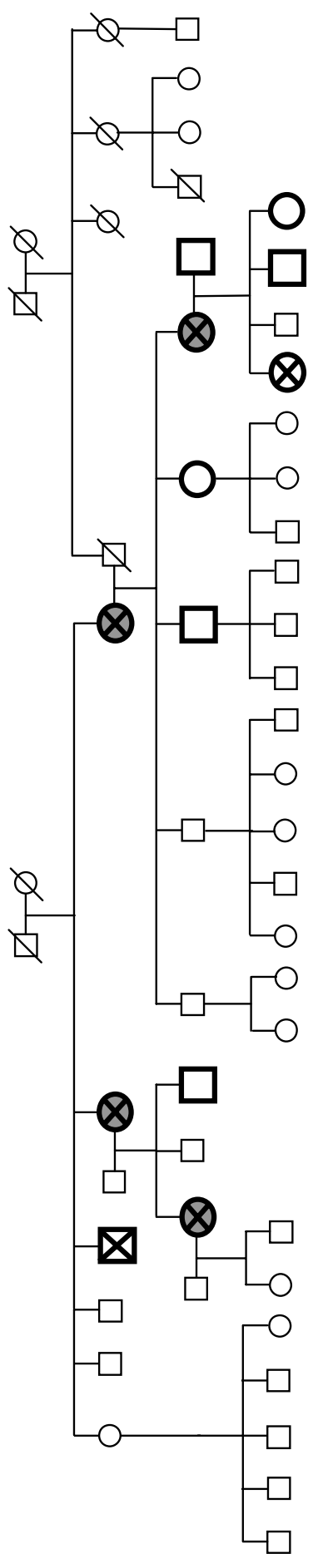

$B C o R-L 1$ expression in cancer and normal cell lines. (a) $B C o R-L 1$ expression in cancer and normal cell lines. (b) Mean and standard deviation of $B C o R-L 1$ expression in cancer and normal cell lines. Normal cell lines: ovarian - OSE 64/96, HOSE 17.1; breast - SVCT,

Bre80hTERT; prostate - RWPE1. BCoR-L1, BCL6 corepressor-like 1; $G A P D H$, glyceraldehyde-3-phosphate dehydrogenase.
Overall, we detected very little variation in the coding region (and surrounding intronic region) of the BCoR-L1 gene in our population of familial cancer cases. The low level of variation detected in the BCoR-L1 gene is consistent with reports that the $\mathrm{X}$ chromosome carries very little variation when compared with autosomal chromosomes [39-41].

\section{BCoR-L1 expression analysis}

To further investigate the role of $B C o R-L 1$ in familial breast cancer and male cancers, we undertook qRT-PCR expression analysis on LCLs from subjects previously screened for $B C o R-L 1$ coding region variation. Alteration of $B C o R-L 1$ expression in LCLs from breast cancer-affected family members may indicate the presence of a regulatory mutation in a noncoding region of the gene. In addition, since various HDACs are aberrantly expressed in a number of cancers susceptible to treatment using HDAC inhibitors [42], including breast cancer [43], we speculated that BCoR-L1, given its association with HDACs, might also be abnormally expressed in breast cancer cases. We thus assessed BCoR- $L 1$ expression in a range of breast, ovarian, and prostate cancer lines.

\section{DID01 expression in lymphoblastoid cell lines and cell lines}

To investigate the suitability of DIDO1 as an LCL expression control, we analysed expression of DIDO1, GAPDH, and $U B C$ in all LCLs and cell lines tested (Figure 4a,b). Interestingly, we found that $D I D O 1$ expression varies considerably less in LCLs than GAPDH or UBC, with GAPDH and $U B C$ showing similar levels of expression variation (Figure $4 \mathrm{a}$ ). The interquartile range for DIDO1 was 2.5-fold and 2.7-fold less than those for $U B C$ and $G A P D H$, respectively. In cancer cell lines, all three expression control genes showed large ranges of expression levels across lines, with GAPDH perhaps showing the least variation (Figure 4b). Therefore, DIDO1 is an improved expression control for LCLs but has variability similar to the commonly used GAPDH control in normal and cancer cell lines.

\section{$B C o R-L 1$ expression in lymphoblastoid cell lines from breast cancer families}

Twenty-nine LCLs from breast cancer cases and their family members ( 23 families in total, including 14 with male breast cancer, 7 with prostate cancer, and $2 B C o R-L 1$ haplotype sharing families) were analysed for changes in $B C o R-L 1$ expression when compared with LCLs from 6 healthy controls (Figure $3 \mathrm{a}-\mathrm{d}$ ). Although expression of $B C o R-L 1$ appeared to be greatly variable, there were no apparent differences in expression levels between breast cancer cases and controls, nor were there any differences between groups when segregated by family cancer type (that is, male breast, prostate, and so on). Likewise, there was no indication of any association between $B C o R-L 1$ genotype and expression. Skewed $\mathrm{X}$ chromosome inactivation data were available for a limited number of samples $(n=8)$. However, skewing did not correlate with 
Table 3

\begin{tabular}{|c|c|c|c|c|c|c|c|c|c|c|c|c|c|c|}
\hline \multirow{2}{*}{$\begin{array}{l}\text { Gene } \\
\text { region } \\
\text { Exon } 4\end{array}$} & \multirow{2}{*}{$\begin{array}{c}\begin{array}{c}\text { Polymerase } \\
\text { chain reaction } \\
\text { fragment }\end{array} \\
4 a\end{array}$} & \multirow{2}{*}{$\begin{array}{c}\begin{array}{c}\text { Nucleotide } \\
\text { change }\end{array} \\
\text { c. } 516 \mathrm{~T}>\mathrm{C}\end{array}$} & \multirow{2}{*}{$\begin{array}{c}\begin{array}{c}\text { Amino } \\
\text { acid } \\
\text { change }\end{array} \\
\text { p.N172N }\end{array}$} & \multicolumn{2}{|c|}{$\begin{array}{c}\text { Number } \\
\text { of total } \\
\text { heterozygous } \\
\text { cases }\end{array}$} & \multicolumn{2}{|c|}{$\begin{array}{c}\text { Male } \\
\text { breast } \\
\text { cancer } \\
\text { families }\end{array}$} & \multicolumn{2}{|c|}{$\begin{array}{c}\text { Prostate } \\
\text { cancer } \\
\text { families }\end{array}$} & \multicolumn{2}{|c|}{$\begin{array}{c}B C o R-\angle 1 \\
\text { haplotype } \\
\text { sharing } \\
\text { families }\end{array}$} & \multicolumn{2}{|c|}{$\begin{array}{l}\text { Number of } \\
\text { heterozygous } \\
\text { controls }\end{array}$} & \multirow{2}{*}{$\begin{array}{c}\text { Previously } \\
\text { reported }\end{array}$} \\
\hline & & & & $2 / 48$ & $4.2 \%$ & & 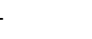 & & - & $2 / 9$ & $22.2 \%$ & $0 / 101$ & $0 \%$ & \\
\hline Exon 4 & $4 b$ & c. $625 \mathrm{G}>\mathrm{A}$ & p.G209S & $6 / 48$ & $12.5 \%$ & $2 / 29 c$ & $6.9 \%$ & $3 / 15$ & $20.0 \%$ & $2 / 9$ & $22.2 \%$ & $18 / 73$ & $24.6 \%$ & Yes \\
\hline Intron 5 & 6 & c. $3608-156 \mathrm{C}>\mathrm{T}$ & - & $2 / 48$ & $4.2 \%$ & & 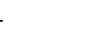 & & - & $2 / 9$ & $22.2 \%$ & $0 / 99$ & $0 \%$ & No \\
\hline Intron 13 & 13 & c. $5075+21 \mathrm{C}>\mathrm{T}$ & - & $10 / 48$ & $20.8 \%$ & $5 / 29 c$ & $17.2 \%$ & $3 / 15$ & $20.0 \%$ & $2 / 9$ & $22.2 \%$ & $26 / 102$ & $25.5 \%$ & Yes \\
\hline
\end{tabular}

Three samples were included in both the male breast cancer family and prostate cancer family categories because they fitted both criteria. Two samples were similarly included in both male breast cancer family and $B C o R-L 1$ haplotype sharing family categories. aMales carrying a variant are homozygous. bReported in dbSNP or SNPper databases. 'One of the variant-carrying subjects possesses a mutation in $B R C A 2$. $B C o R-\angle 1$, BCL6 corepressor-like 1.

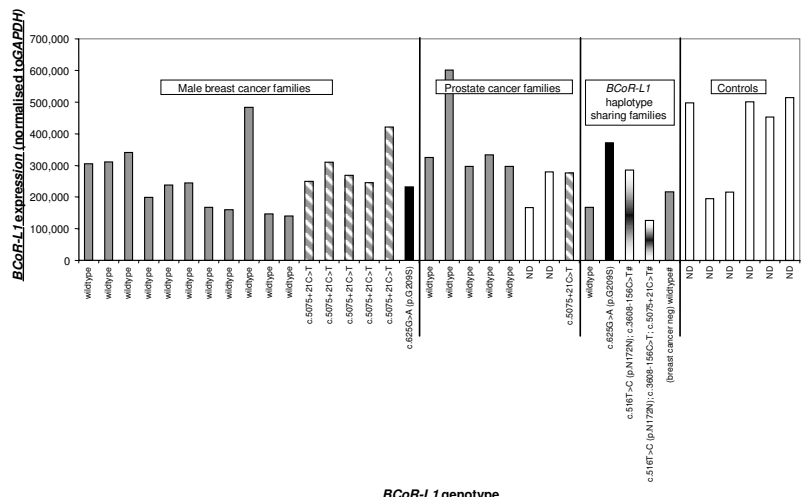

BCoR-L1genotve

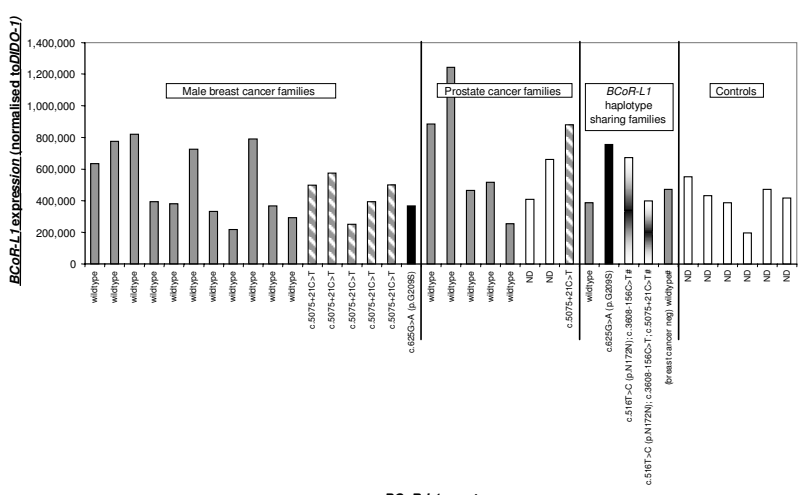

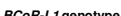
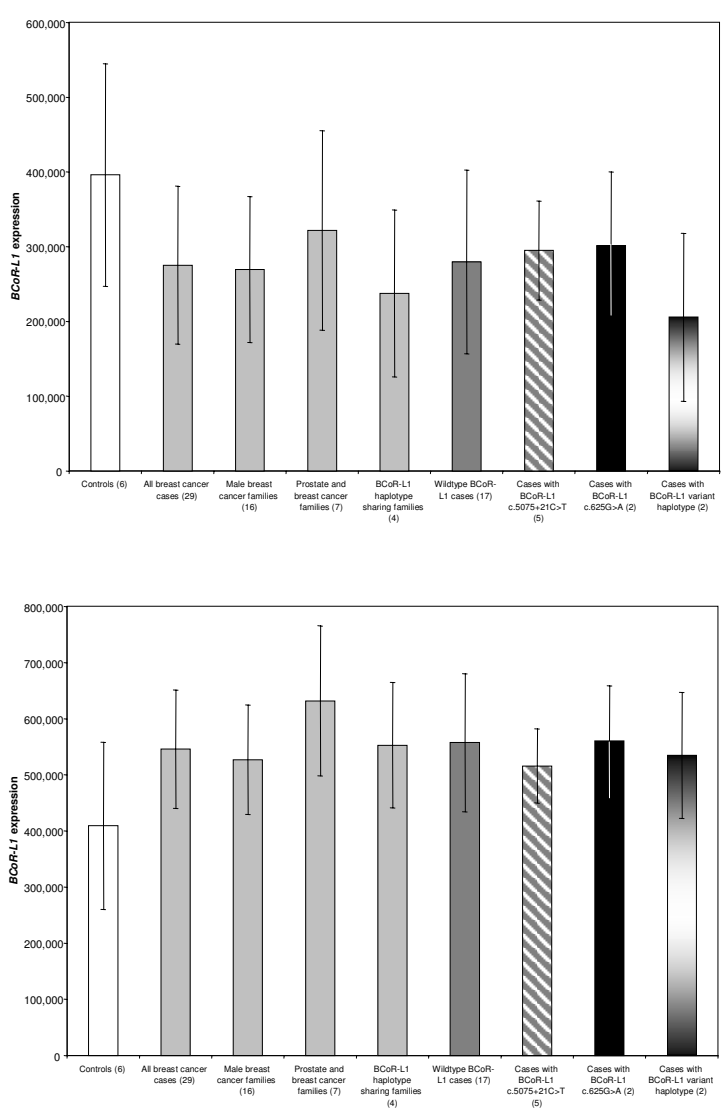

$B C o R-L 1$ haplotype sharing family pedigree detailing carriers of the c.516T>C and c.3608-156C $>$ T variants. $\otimes=$ breast cancer-positive; c.516T>C and c.3608-156C>T-positive. $\otimes=$ breast cancer-negative; c.516T>C and c.3608-156C>T-positive. $\square=$ breast cancer-negative; c.516T $>C$ and c.3608-156C $>$ T-negative. Circle $=$ female, square $=$ male; subjects marked by small shapes were not available for genotyping. $B C o R-L 1$, BCL6 corepressor-like 1. 
Figure 3
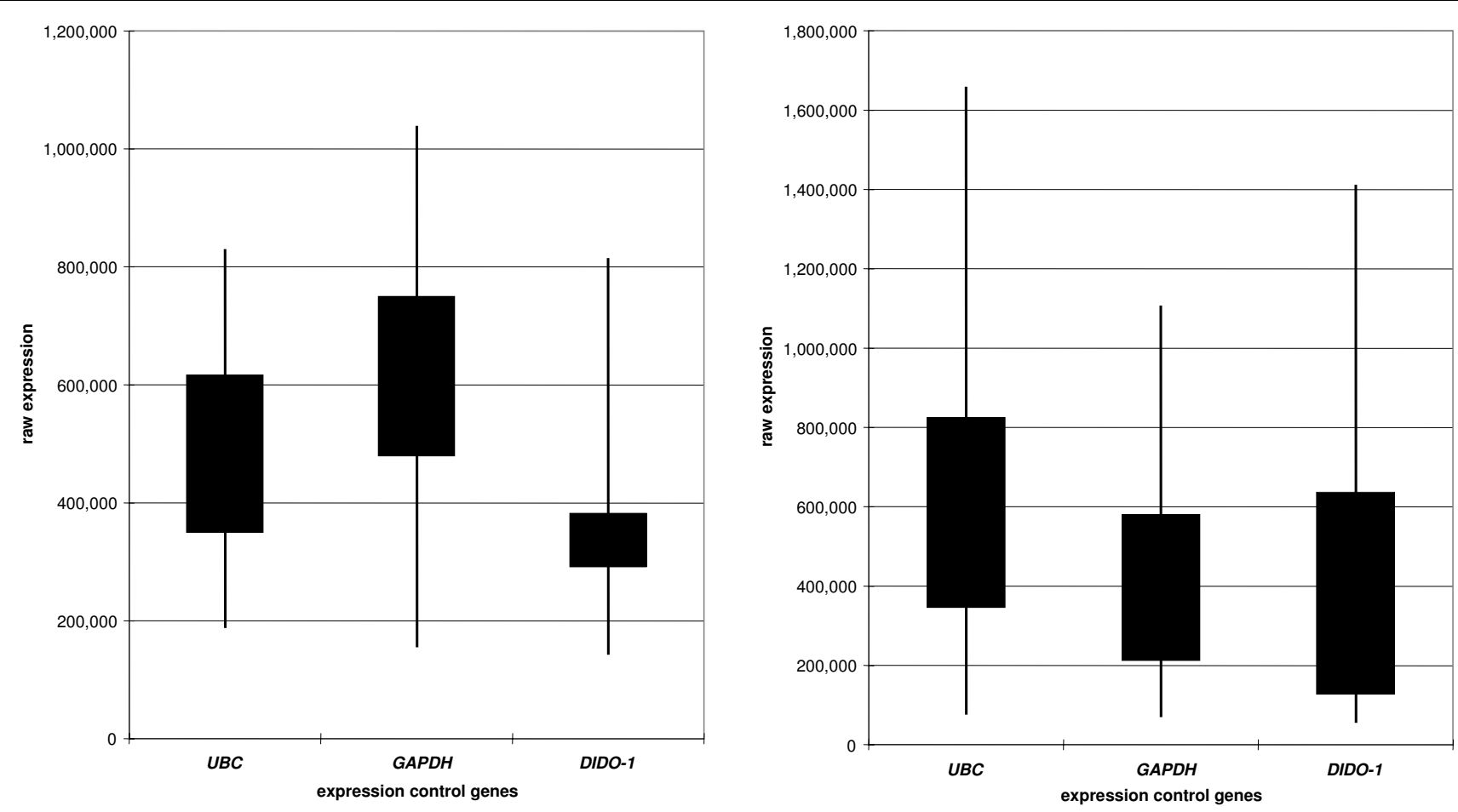

$B C o R-L 1$ expression in lymphoblastoid cell lines (LCLs) from breast cancer families. (a) BCoR- $L 1$ expression in LCLs from breast cancer families (normalised to GAPDH). (b) BCoR-L1 expression in LCLs from breast cancer families (normalised to DIDO-1). (c) Mean and standard deviation of $B C o R-L 1$ expression in samples, grouped according to type of family cancer or $B C o R-L 1$ genotype (normalised to GAPDH). (d) Mean and standard deviation of $B C o R-L 1$ expression in samples, grouped according to type of family cancer or $B C o R-L 1$ genotype (normalised to $D I D O-1$ ). *Subject also carries a BRCA2 mutation. \#Subjects from the same BCoR-L1 haplotype sharing family. BCoR-L1, BCL6 corepressor-like 1; DIDO1, death inducer-obliterator 1; GAPDH, glyceraldehyde-3-phosphate dehydrogenase.

$B C o R-L 1$ expression or genotype (data not shown). Results correlating expression with sample source or sample genotype were similar using GAPDH (Figure 3a,c) or DIDO1 (Figure $3 b, d$ ) normalisation, although the decreased variability observed in normal controls for DIDO1 normalisation supported our earlier observations that DIDO1 is an improved control for LCL expression analysis. The standard deviation of expression in control LCLs was approximately $20 \%$ less for DIDO1 compared with GAPDH. Overall, it appears that $B C o R-L 1$ expression is not altered in familial breast cancer cases, even for subgroups defined by male cancer type, and it is unlikely that there is any variation in the $B C o R-L 1$ gene (detected or otherwise) which has a profound effect on expression.

\section{$B C o R-L 1$ expression in cancer and normal cell lines}

To assess a possible role for $B C o R-L 1$ in tumourigenesis, we also analysed $B C o R-L 1$ expression in various ovarian, breast, and prostate cancer and normal cell lines (Figure 1a,b). Most normal and cancer cell lines exhibited increased expression levels compared with LCLs. Once again, it was observed that $B C o R-L 1$ expression is highly variable in both cancer and normal cell lines, with up to 13-fold differences in expression observed. There were no significant differences between the mean $B C$ oR- $L 1$ expression in normal cell lines compared with cancer cell lines, but individual ovarian and breast cancer cell lines showed significantly increased expression compared with the mean expression in normal cell lines. Markedly elevated levels of $B C o R-L 1(P<0.05)$ were observed for a total of $4 / 10$ ovarian cancer cell lines (OVCAR3, SKOV3, A2780, $27 / 87$; 4-fold to 13 -fold upregulation compared with the HOSE17.1 normal ovarian epithelial control) and 2/13 breast cancer cell lines (BT20 and T47D; 3-fold and 4-fold upregulation compared with SVCT normal breast control). This was interesting, considering that skewed $\mathrm{X}$ inactivation has been reported in ovarian cancer cases [19]. It would also seem to suggest that dysregulation of expression in the form of upregulation may play a role in tumourigenesis. However, a study using a $B C o R-L 1$-containing Affymetrix microarray (Affymetrix, Santa Clara, CA, USA) did not provide any evidence for $B C o R-L 1$ deregulation in ovarian cancers [44]. Comparison of gene expression between 37 advanced-stage serous ovarian carcinomas and normal ovarian surface epithelium cytobrushings revealed that $B C o R-L 1$ was not one of 1,191 genes that were significantly differentially regulated (defined as greater than or equal to 1.5 -fold change in expression). This contrasts 

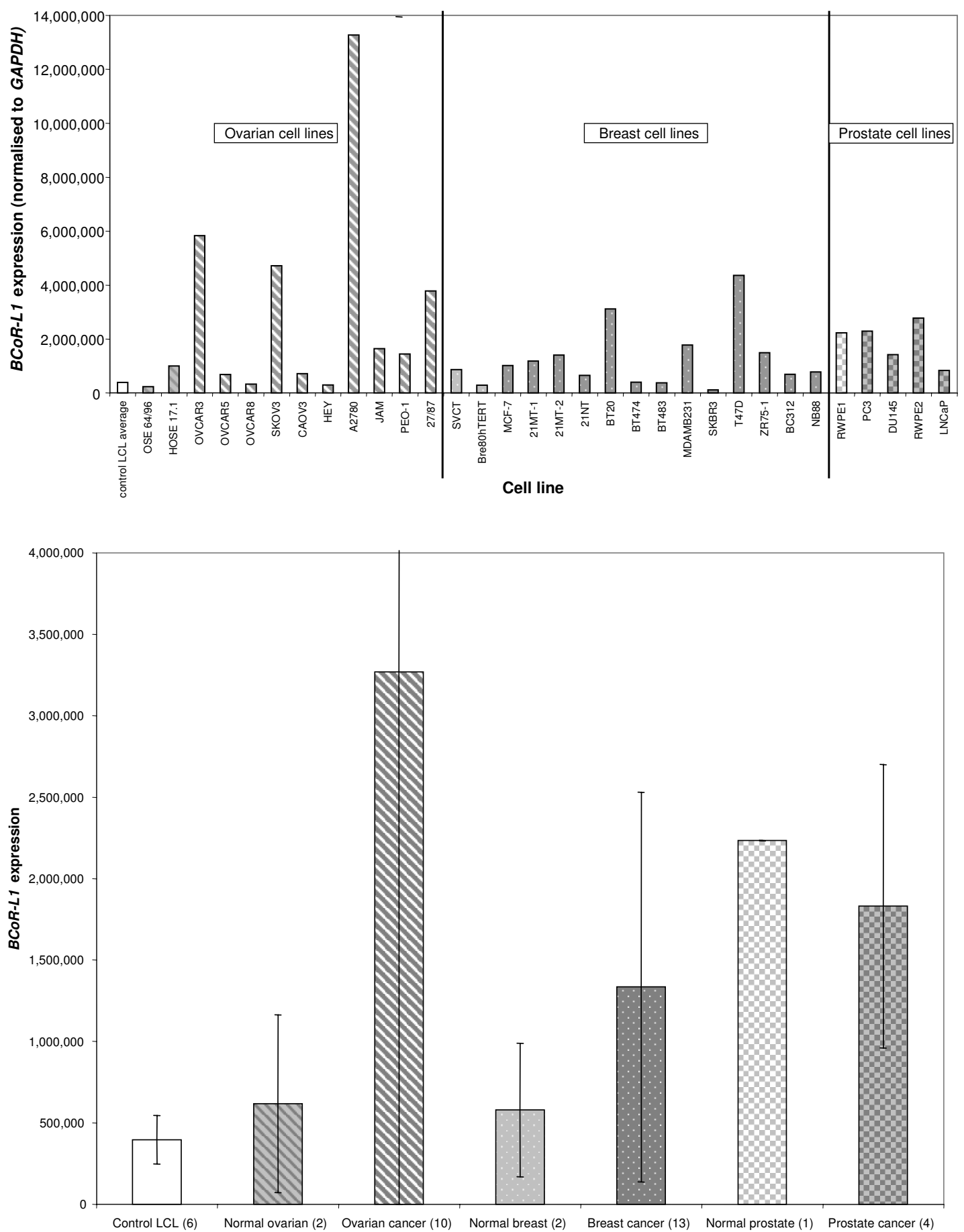

Variation in control gene expression. (a) Variation in control gene expression in lymphoblastoid cell lines. (b) Variation in control gene expression in cell lines. DIDO-1, death inducer-obliterator 1; GAPDH, glyceraldehyde-3-phosphate dehydrogenase; UBC, ubiquitin C. 
with the 4- to 13-fold increased expression we observed for specific cancer lines compared with normal ovarian epithelial cell lines.

There was no evidence that the hormone receptor status of each cell line correlated with these $B C o R-L 1$ expression differences because the highly estrogen receptor (ER)- and progesterone receptor (PR)-positive breast cancer cell line T47D showed similar BCoR- $L 1$ expression to BT20, a breast cancer cell line that does not express ER or PR [45]. In addition, the ovarian cancer cell lines OVCAR3 (ER-positive) and SKOV3 (ER-negative) expressed similar levels of $B C o R-L 1$ [46]. Investigation of the $\mathrm{X}$ chromosome karyotype of these ovarian cancer cell lines did reveal a possible relationship with $B C o R$ $L 1$ expression. Karyotype data were available for OVCAR3, SKOV3, OVCAR5, and OVCAR8 [47], with the BCoR-L1overexpressing lines OVCAR3 and SKOV3 found to possess three copies of $\mathrm{Xq}$ and four $\mathrm{X}$ chromosomes, respectively. Conversely, OVCAR5 and OVCAR8 each possess only one $X$ chromosome and express normal levels of $B C o R-L 1$. Information on the $\mathrm{X}$ chromosome karyotype of breast cancer cell lines was limited, but there was no indication of an association between karyotype and $B C o R-L 1$ expression $[47,48]$. The finding that $B C o R-L 1$ expression tends to correlate with supernumary $\mathrm{X}$ chromosomes suggests that this overexpression probably does not contribute to carcinogenesis but may occur as a result of carcinogenesis. Although it is unknown whether the superfluous $X$ chromosomes in OVCAR3 and SKOV3 are active, it has been reported that ovarian (and breast) tumours can possess multiple active $\mathrm{X}$ chromosomes [48-51].

\section{Conclusion}

The aim of the present study was to attempt to elucidate a role for $B C o R-L 1$ as a high-risk breast cancer predisposition gene by mutation screening of well-characterised non-BRCA1/2 familial breast cancer subjects who were selected to maximise the probability of identifying a mutation. We detected minimal variation in the coding region of $B C o R-L 1$, which may imply the importance of maintaining the structural integrity of the $B C o R-L 1$ protein. It is also unlikely that noncoding region variation in the $B C o R-L 1$ gene is involved in breast cancer predisposition as we did not detect any significant changes in expression between cancer cases and cell lines and controls. The absence of pathogenic coding mutations or expression deregulation in this set of familial cases indicates that $B C o R$ $L 1$ is extremely unlikely to be a major high-risk familial breast cancer predisposition gene. However, it is still possible that $B C o R-L 1$ could be involved in breast cancer predisposition as a moderate- or low-penetrance risk gene, as has been found with CHEK2 [6], BRIP1 [7], and PALB2 [8,9] in large studies of $B R C A X$ cases and controls. The involvement of $B C o R-L 1$ in ovarian cancer may also be worthy of investigation, and further functional analysis of the BCoR-L1 protein will help to elu- cidate the involvement of BCoR-L1 in various essential pathways.

\section{Competing interests}

The authors declare that they have no competing interests.

\section{Authors' contributions}

FL carried out the screening of the gene and the $\mathrm{LOH}$ and expression analysis and drafted the manuscript. JA provided RNA from all of the breast and ovarian cell lines. GJM and GMP performed haplotype sharing analysis. CJB performed the $X$ inactivation status analysis and drafted the relevant section of the manuscript. DBY contributed to the experimental study design and provided sequence data on $B C o R-L 1$. $\mathrm{kConFab}$ recruited and collected subjects for the study. GC-T and KKK participated in the design and coordination of the study. ABS conceived the study, participated in its design and coordination, and helped to draft the manuscript. All authors read and approved the final manuscript.

\section{Acknowledgements}

The authors thank Heather Thorne, Eveline Niedermayr, Lynda Williams, Danni Surace, and all the kConFab research nurses and staff, the heads and staff of the Family Cancer Clinics, and the Clinical Follow Up Study (funded by National Health and Medical Research Council [NHMRC] grants 145684 and 288704) for their contributions to this resource and the many families who contribute to kConFab. kConFab is supported by grants from the National Breast Cancer Foundation and the NHMRC and by the Queensland Cancer Fund, the Cancer Councils of New South Wales, Victoria, Tasmania, and South Australia, and the Cancer Foundation of Western Australia. The authors thank Helene Holland for supplying data and Anna Marsh for technical advice and assistance on DHPLC. Judith Clements and Ying Dong supplied prostate cancer cell lines used in this study, and Vivien G Cheung kindly made available unpublished data on mRNA expression levels in LCLs. This research was supported by grants from the Queensland Cancer Fund and National Breast Cancer Foundation. GC-T and KKK are NHMRC Principal Research Fellows, and ABS is funded by an NHMRC Career Development Award.

\section{References}

1. Peto J, Collins N, Barfoot R, Seal S, Warren W, Rahman N, Easton DF, Evans C, Deacon J, Stratton MR: Prevalence of BRCA1 and BRCA2 gene mutations in patients with early-onset breast cancer. J Natl Cancer Inst 1999, 91:943-949.

2. Ford D, Easton DF, Stratton M, Narod S, Goldgar D, Devilee P, Bishop DT, Weber B, Lenoir G, Chang-Claude J, et al.: Genetic heterogeneity and penetrance analysis of the BRCA1 and BRCA2 genes in breast cancer families. The Breast Cancer Linkage Consortium. Am J Hum Genet 1998, 62:676-689.

3. Sidransky D, Tokino T, Helzlsouer K, Zehnbauer B, Rausch G, Shelton B, Prestigiacomo L, Vogelstein B, Davidson N: Inherited p53 gene mutations in breast cancer. Cancer Res 1992, 52:2984-2986.

4. Chenevix-Trench G, Spurdle AB, Gatei M, Kelly H, Marsh A, Chen X, Donn K, Cummings M, Nyholt D, Jenkins MA, et al.: Dominant negative ATM mutations in breast cancer families. I Natl Cancer Inst 2002, 94:205-215.

5. Lynch ED, Ostermeyer EA, Lee MK, Arena JF, Ji H, Dann J, Swisshelm K, Suchard D, MacLeod PM, Kvinnsland S, et al: Inherited mutations in PTEN that are associated with breast cancer, cowden disease, and juvenile polyposis. Am J Hum Genet 1997, 61:1254-1260. 
6. Bernstein JL, Teraoka SN, John EM, Andrulis IL, Knight JA, Lapinski R, Olson ER, Wolitzer AL, Seminara D, Whittemore AS, et al:: The CHEK2*1100delC allelic variant and risk of breast cancer: screening results from the Breast Cancer Family Registry. Cancer Epidemiol Biomarkers Prev 2006, 15:348-352.

7. Seal S, Thompson D, Renwick A, Elliott A, Kelly P, Barfoot R, Chagtai T, Jayatilake $\mathrm{H}$, Ahmed M, Spanova K, et al:: Truncating mutations in the Fanconi anemia J gene BRIP1 are low-penetrance breast cancer susceptibility alleles. Nat Genet 2006, 38:1239-1241.

8. Erkko H, Xia B, Nikkila J, Schleutker J, Syrjakoski K, Mannermaa A, Kallioniemi A, Pylkas K, Karppinen SM, Rapakko K, et al.: A recurrent mutation in PALB2 in Finnish cancer families. Nature 2007, 446:316-319.

9. Rahman N, Seal S, Thompson D, Kelly P, Renwick A, Elliott A, Reid S, Spanova K, Barfoot R, Chagtai T, et al.: PALB2, which encodes a BRCA2-interacting protein, is a breast cancer susceptibility gene. Nat Genet 2007, 39:165-167.

10. Pagan JK, Arnold J, Hanchard KJ, Kumar R, Bruno T, Jones MJ, Richard DJ, Forrest A, Spurdle A, Verdin E, et al:: A novel corepressor, BCoR-L1, represses transcription through an interaction with CtBP. J Biol Chem 2007, 282:15248-15257.

11. Jepsen K, Rosenfeld MG: Biological roles and mechanistic actions of co-repressor complexes. J Cell Sci 2002, 115(Pt 4):689-698.

12. Hanahan D, Weinberg RA: The hallmarks of cancer. Cell 2000, 100:57-70.

13. Rosen EM, Fan S, Pestell RG, Goldberg ID: BRCA1 gene in breast cancer. J Cell Physio/ 2003, 196:19-41.

14. van 't Veer LJ, Dai H, van de Vijver MJ, He YD, Hart AA, Mao M, Peterse HL, van der Kooy K, Marton MJ, Witteveen AT, et al.: Gene expression profiling predicts clinical outcome of breast cancer. Nature 2002, 415:530-536.

15. Loupart ML, Adams S, Armour JA, Walker R, Brammar W, Varley J: Loss of heterozygosity on the $\mathrm{X}$ chromosome in human breast cancer. Genes Chromosomes Cancer 1995, 13:229-238.

16. Choi C, Cho S, Horikawa I, Berchuck A, Wang N, Cedrone E, Jhung SW, Lee JB, Kerr J, Chenevix-Trench G, et al.: Loss of heterozygosity at chromosome segment Xq25-26.1 in advanced human ovarian carcinomas. Genes Chromosomes Cancer 1997, 20:234-242.

17. Choi C, Kim MH, Juhng SW: Loss of heterozygosity on chromosome XP22.2-p22.13 and Xq26.1-q27.1 in human breast carcinomas. J Korean Med Sci 1998, 13:311-316.

18. Carrel L, Willard HF: X-inactivation profile reveals extensive variability in $\mathrm{X}$-linked gene expression in females. Nature 2005, 434:400-404.

19. Buller RE, Sood AK, Lallas T, Buekers T, Skilling JS: Association between nonrandom X-chromosome inactivation and BRCA1 mutation in germline DNA of patients with ovarian cancer. $J$ Natl Cancer Inst 1999, 91:339-346.

20. Kristiansen M, Langerod A, Knudsen GP, Weber BL, BorresenDale AL, Orstavik KH: High frequency of skewed $X$ inactivation in young breast cancer patients. J Med Genet 2002, 39:30-33.

21. Kristiansen M, Knudsen GP, Maguire $P$, Margolin S, Pedersen J, Lindblom A, Orstavik KH: High incidence of skewed $X$ chromosome inactivation in young patients with familial non-BRCA1/ BRCA2 breast cancer. J Med Genet 2005, 42:877-880.

22. Mann GJ, Thorne H, Balleine RL, Butow PN, Clarke CL, Edkins E, Evans GM, Fereday S, Haan E, Gattas M, et al:: Analysis of cancer risk and BRCA1 and BRCA2 mutation prevalence in the kConFab familial breast cancer resource. Breast Cancer Res 2006, 8:R12.

23. National Breast Cancer Centre: Advice about familial aspects of breast cancer and epithelial ovarian cancer: a guide for health professionals. [http://www.nbcc.org.au/bestpractice/resources/ BOG182 adviceaboutfamiliala.pdfl.

24. Rozen S, Skaletsky HJ: Primer3 on the WWW for general users and for biologist programmers. Bioinformatics: Methods and Protocols (Methods in Molecular Biology) 2000:365-386 [http:// frodo.wi.mit.edu/primer3/input.htm]. Totowa, NJ: Humana Press Inc

25. Jones AC Austin J, Hansen N, Hoogendoorn B Oefner PJ, Cheadle JP, O'Donovan MC: Optimal temperature selection for mutation detection by denaturing HPLC and comparison to single-stranded conformation polymorphism and heteroduplex analysis. Clin Chem 1999, 45(8 Pt 1):1133-1140.
26. Levi S, Urbano-Ispizua A, Gill R, Thomas DM, Gilbertson J, Foster $\mathrm{C}$, Marshall CJ: Multiple K-ras codon 12 mutations in cholangiocarcinomas demonstrated with a sensitive polymerase chain reaction technique. Cancer Res 1991, 51:3497-3502.

27. Vandesompele J, De Preter K, Pattyn F, Poppe B, Van Roy N, De Paepe A, Speleman F: Accurate normalization of real-time quantitative RT-PCR data by geometric averaging of multiple internal control genes. Genome Biol 2002, 3:RESEARCH0034.

28. Cheung VG, Conlin LK, Weber TM, Arcaro M, Jen KY, Morley M, Spielman RS: Natural variation in human gene expression assessed in lymphoblastoid cells. Nat Genet 2003, 33:422-425.

29. PubMed query.fcgi?CMD=search\&DB=pubmed]

30. Gabellini D, Green MR, Tupler R: When enough is enough: genetic diseases associated with transcriptional derepression. Curr Opin Genet Dev 2004, 14:301-307.

31. Thiel G, Lietz $M$, Hohl M: How mammalian transcriptional repressors work. Eur J Biochem 2004, 271:2855-2862.

32. Zuker M: Mfold web server for nucleic acid folding and hybridization prediction. Nucleic Acids Res 2003, 31:3406-3415.

33. Schwartz S, Zhang Z, Frazer KA, Smit A, Riemer C, Bouck J, Gibbs $\mathrm{R}$, Hardison R, Miller W: PipMaker - a web server for aligning two genomic DNA sequences. Genome Res 2000, 10:577-586.

34. Cartegni L, Wang J, Zhu Z, Zhang MQ, Krainer AR: ESEfinder: a web resource to identify exonic splicing enhancers. Nucleic Acids Res 2003, 31:3568-3571.

35. Fairbrother WG, Yeh RF, Sharp PA, Burge CB: Predictive identification of exonic splicing enhancers in human genes. Science 2002, 297:1007-1013.

36. Nakamura $Y$, Gojobori T, Ikemura T: Codon usage tabulated from international DNA sequence databases: status for the year 2000. Nucleic Acids Res 2000, 28:292.

37. Alex Dong Li's SpliceSiteFinder [http://www.genet.sick kids.on.ca/ ali/splicesitefinder.html]

38. $\mathrm{Ng} \mathrm{PC}$, Henikoff $\mathrm{S}$ : Predicting deleterious amino acid substitutions. Genome Res 2001, 11:863-874.

39. Ross MT, Grafham DV, Coffey AJ, Scherer S, McLay K, Muzny D, Platzer M, Howell GR, Burrows C, Bird CP, et al:: The DNA sequence of the human X chromosome. Nature 2005, 434:325-337.

40. Tsui C, Coleman LE, Griffith JL, Bennett EA, Goodson SG, Scott JD, Pittard WS, Devine SE: Single nucleotide polymorphisms (SNPs) that map to gaps in the human SNP map. Nucleic Acids Res 2003, 31:4910-4916.

41. International HapMap Consortium: A haplotype map of the human genome. Nature 2005, 437:1299-1320.

42. Johnstone RW: Histone-deacetylase inhibitors: novel drugs for the treatment of cancer. Nat Rev Drug Discov 2002, 1:287-299.

43. Kawai H, Li H, Avraham S, Jiang S, Avraham HK: Overexpression of histone deacetylase HDAC1 modulates breast cancer progression by negative regulation of estrogen receptor alpha. Int $J$ Cancer 2003, 107:353-358.

44. Donninger $\mathrm{H}$, Bonome $\mathrm{T}$, Radonovich $\mathrm{M}$, Pise-Masison $\mathrm{CA}$, Brady $\mathrm{J}$, Shih $\mathrm{JH}$, Barrett JC, Birrer MJ: Whole genome expression profiling of advance stage papillary serous ovarian cancer reveals activated pathways. Oncogene 2004, 23:8065-8077.

45. Walsh MD, Luckie SM, Cummings MC, Antalis TM, McGuckin MA Heterogeneity of MUC1 expression by human breast carcinoma cell lines in vivo and in vitro. Breast Cancer Res Treat 1999, 58:255-266.

46. Treeck O, Haldar C, Ortmann O: Antiestrogens modulate MT1 melatonin receptor expression in breast and ovarian cancer cell lines. Oncol Rep 2006, 15:231-235.

47. Roschke AV, Tonon G, Gehlhaus KS, McTyre N, Bussey KJ, Lababidi S, Scudiero DA, Weinstein JN, Kirsch IR: Karyotypic complexity of the $\mathrm{NCl}-60$ drug-screening panel. Cancer Res 2003 63:8634-8647.

48. Sirchia SM, Ramoscelli L, Grati FR, Barbera F, Coradini D, Rossella F, Porta G, Lesma E, Ruggeri A, Radice P, et al.: Loss of the inactive $X$ chromosome and replication of the active $X$ in BRCA1-defective and wild-type breast cancer cells. Cancer Res 2005, 65:2139-2146.

49. Kimmel VM: Clinical-cytological correlations of mammary carcinoma based upon sex-chromatin counts. Cancer 1957, 10:922-927 
Breast Cancer Research Vol 9 No 4 Lose et al.

50. Wang N, Cedrone E, Skuse GR, Insel R, Dry J: Two identical active $\mathrm{X}$ chromosomes in human mammary carcinoma cells. Cancer Genet Cytogenet 1990, 46:271-280.

51. Benoit MH, Hudson TJ, Maire G, Squire JA, Arcand SL, Provencher D, Mes-Masson AM, Tonin PN: Global analysis of chromosome $X$ gene expression in primary cultures of normal ovarian surface epithelial cells and epithelial ovarian cancer cell lines. Int J Onco/ 2007, 30:5-17. 